\title{
PENGEMBANGAN APLIKASI MANAJEMEN KEPEGAWAIAN PADA BADAN PERTANAHAN NASIONAL KOTA DEPOK
}

\author{
Reza Saputra \\ Teknik Informatika, Fakultas Teknik, Universitas Pamulang \\ Jalan Puspitek, Kelurahan Buaran, Kecamatan Pamulang Kota Tangerang Selatan, Banten 15310 \\ reza24.saputra@gmail.com
}

\begin{abstract}
ABSTRAK
Permasalahan yang terdapat pada Badan Pertanahan Nasional Kota Depok yaitu proses pendataan manajemen kepegawaian masih menggunakan sistem manual dimana pencatatan dan laporan masih dilakukan dengan pencatatan ke dalam buku sehingga sulit untuk mengetahui data absensi, data cuti dan data gaji karyawan. Tujuan merancang suatu aplikasi ini menerapkan perluasan sarana kerja berbasis teknologi tinggi yang mudah namun efektif dalam rangka peningkatan kualitas pelayanan secara internal maupun eksternal dan terwujudnya paperless office yang secara tidak langsung merupakan upaya dukungan pada kerangka besar efektivitas kerja. Perangkat aplikasi yang telah dibuat dengan bahasa pemrograman Java NetBeans 8.0.2 dan penyimpanan data pada database MySQL dapat memberikan kelancaran dalam proses menginput dan penyimpanan data-data serta laporan-laporan yang diberikan kepada pimpinan perusahaan. Dengan menggunakan metode pengembangan sistem yaitu Waterfall dalam penelitian ini adalah dengan tahapan-tahapan seperti rekayasa sistem, analisis, desain, coding, testing, dan maintenance. Hasil dari penelitian ini menciptakan aplikasi manajemen kepegawaian yang sesuai dengan kebutuhan dan mudah digunakan oleh admin.
\end{abstract}

Kata Kunci: Aplikasi, Manajemen, Pegawai, Desktop

\begin{abstract}
The problem that exists in the National Land Agency of Depok City is that the data collection process for personnel management still uses a manual system where recording and reports are still carried out by recording into a book so it is difficult to find out attendance data, leave data and employee salary data. The purpose of designing an application is to implement an easy but effective expansion of high technology-based work facilities in order to improve the quality of services internally and externally and to realize a paperless office which indirectly is an effort to support the broad framework of work effectiveness. Application tools that have been created using the Java NetBeans 8.0.2 programming language and data storage in the MySQL database can provide smooth processing of input and storage of data and reports provided to company leaders. By using the system development method, namely Waterfall, in this research, the stages are systems engineering, analysis, design, coding, testing, and maintenance. The results of this study create a personnel management application that fits the needs and is easy to use by admins.
\end{abstract}

Keyword: Application, Management, Employees, Desktop

\section{PENDAHULUAN}

Kantor Pertanahan Badan Pertanahan Nasional (BPN) di Kota Depok belum memiliki sistem informasi yang terstruktur dan terintegrasi dengan baik, artinya semua sistem yang dijalankan masih bersifat semi komputer yaitu dengan menggunakan Microsoft Excel, dan sebagian besar arus informasi menggunakan sistem manual (Fachlevi \& Syafariani, 2017). Dan bahkan dalam penggunaan aplikasi pendataan pegawai hanya dapat diakses oleh bagian administrasi kepegawaian (Priansa, 2017).

Faktanya pegawai memerlukan sarana untuk dengan mudah melihat informasi biodata dirinya, informasi laporan absensi, informasi laporan cuti, dan informasi laporan gaji. Aplikasi yang ada saat ini tidak memberikan fasilitas-fasilitas tersebut (Kodarisman \& Nugroho, 2013).

Dengan permasalahan tersebut, perlu ada nya suatu sistem yang terkomputerisasi dalam penyelesaiannya. Sistem adalah sekelompok unsur yang erat hubungannya satu dengan yang lain, yang berfungsi bersama-sama untuk mencapai tujuan (Sutabri, 2012). Sistem merupakan suatu kumpulan dari komponen-komponen yang membentuk satu kesatuan (Tyoso, 2016). Pembangunan sistem adalah sekumpulan aktivitas yang menggambarkan secara rinci bagaimana sistem akan berjalan. Hal itu bertujuan untuk 
menghasilkan produk perangkat lunak yang sesuai dengan kebutuhan user (Satzinger, J. W., Jackson, R. B., Burd, n.d.).

Aplikasi kepegawaian di Kantor Pertanahan BPN Kota Depok, terutama untuk pencatatan data laporan diri pegawai, laporan absensi, laporan cuti, dan laporan gaji. Aplikasi yang dirancang akan memberikan keuntungan dalam hal konsistensi data, karena data tersimpan pada satu komputer. Data yang tersentralisasi juga memberikan kemudahan dalam pencarian. Informasi di dalam sistem juga mudah diakses dari berbagai tempat, selama tersedia koneksi jaringan internet (Tani, Bagre, \& Adam, 2018).

Diharapkan dengan adanya suatu sistem informasi dapat menangani permasalahan yang ada di perusahaan tersebut. Sistem adalah setiap sesuatu terdiri dari obyek-obyek, atau unsur-unsur, atau komponen-komponen yang bertata kaitan dan bertata hubungan satu sama lain, sedemikian rupa sehingga unsurunsur tersebut merupakan satu kesatuan pemrosesan atau pengolahan yang tertentu. (Prasojo, 2011)

Aplikasi ini dapat memudahkan pekerjaan admin perusahaan dalam melaksanakan pembuatan laporan dan mempercepat dalam proses penginputan data serta pencarian data di Badan Pertanahan Nasional Kota Depok.

\section{METODE PENELITIAN}

Peneliti menggunakan metode Research and Development daam penyelesaian penelitian ini. (Sugiyono, 2016). Dalam pelaksanaan $\mathrm{R} \& \mathrm{D}$, ada beberapa metode yang digunakan yaitu metode deskriptif, evaluatif dan eksperimental. Metode penelitian deskriptif digunakan dalam penelitian awal untuk menghimpun data tentang kondisi yang ada yaitu penulis membutuhkan data-data yang dapat menunjang tercipta nya suatu aplikasi manajemen kepegawaian seperti data pegawai, data absensi, data cuti dan data gaji terdahulu yang masih tersimpan secara manual didalam buku besar. Metode evaluatif digunakan untuk mengevaluasi proses ujicoba pengembangan suatu produk, dalam proses ini penulis melakukan ujicoba terhadap suatu sistem yang telah dirancang agar tidak ada terjadi kesalahan dalam proses penginputan data serta pelaporan bulanan kepada pimpinan perusahaan. Dan metode eksperimen digunakan untuk menguji keampuhan dari produk yang dihasilkan, dalam proses yang terakhir ini perlu dilakukan pengujian akhir yang diharapkan bahwa sistem yang dirancang oleh penulis dapat berjalan dengan baik dan sesuai dengan kebutuhan dan terfokus pada proses manajemen kepegawaian Badan Pertanahan Nasional Kota Depok (Putra, 2011).

Model pengembangan sistem yang digunakan adalah Waterfall. Model alur terjun menyediakan pendekatan alur hidup perangkat lunak secara sekuensial atau terurut dimulai dari analisis kebutuhan, desain, pengkodean, pengujian dan tahap pendukung (Syarif, Pratama, Bina, Informatika, \& Barat, 2021).

\section{HASIL DAN PEMBAHASAN}

\section{Alternatif Penyelesaian Masalah}

Berdasarkan masalah-masalah yang telah dianalisa pada Badan Pertanahan Nasional Kota Depok, maka penulis memberikan alternatif penyelesaian masalah, yaitu:

1. Aplikasi manajemen kepegawaian yang terkomputerisasi harus segera dilaksanakan sehingga dapat menghasilkan informasi yang cepat, tepat dan akurat.

2. Perancangan database secara komputerisasi untuk aplikasi manajemen kepegawaian sehingga mempermudah penyimpanan data tidak menggunakan media kertas lagi melainkan berupa hard disk atau media penyimpanan elektronik lainnya.

3. Perlunya sumber daya manusia yang terampil agar mampu membuat dan menjalankan aplikasi tersebut dengan baik dan rapih.

4. Pengembangan aplikasi manajemen kepegawaian yang mudah dipahami oleh setiap user agar kinerjanya lebih cepat dalam menghasilkan laporan. 


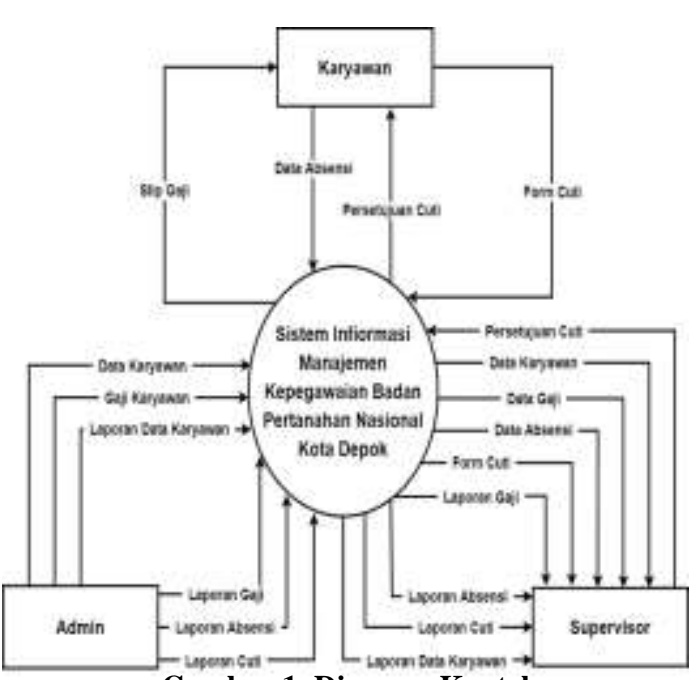

Gambar 1. Diagram Konteks

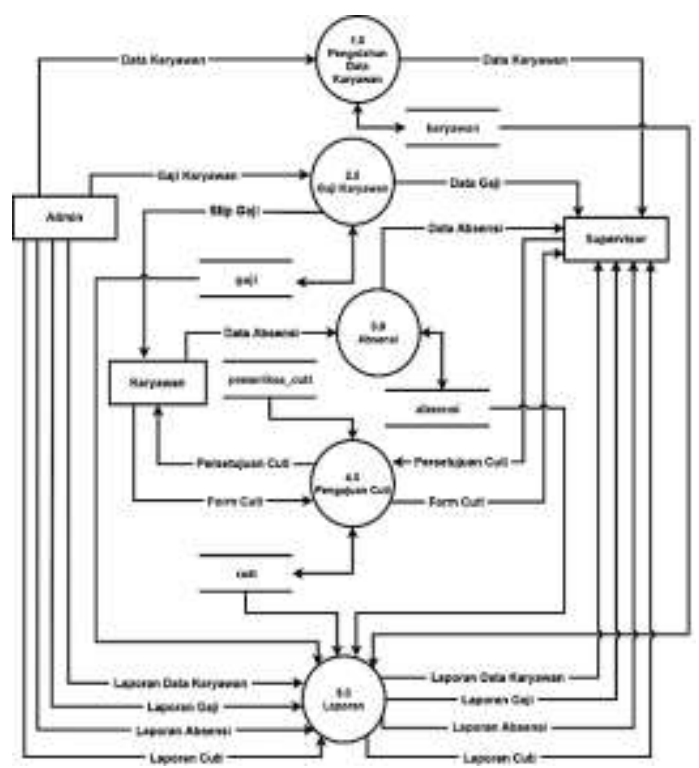

Gambar 2. Diagram Nol

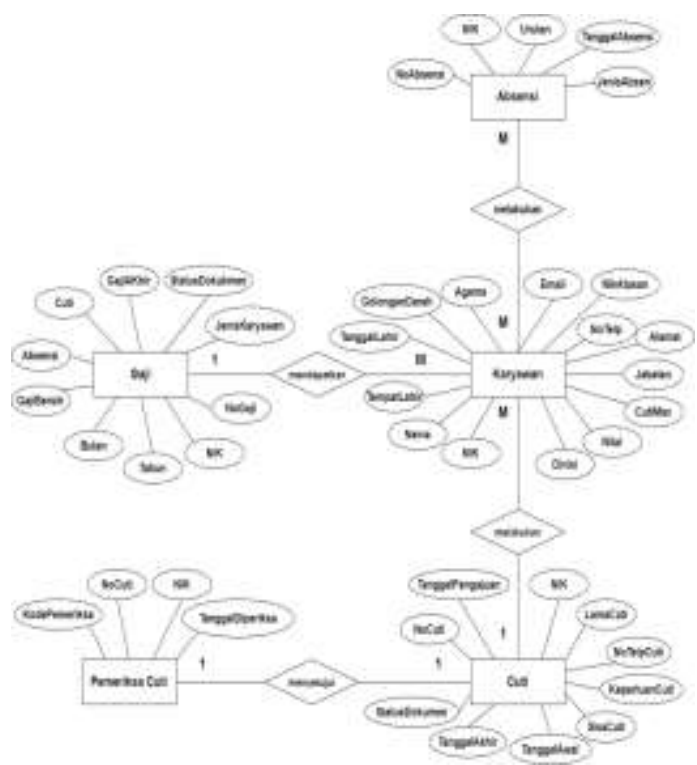

Gambar 3. ERD (Entity Relationship Diagram)
Berikut adalah tampilan layar dan hasil pengujian pada software program yang telah di buat dengan bahasa pemrograman Java.

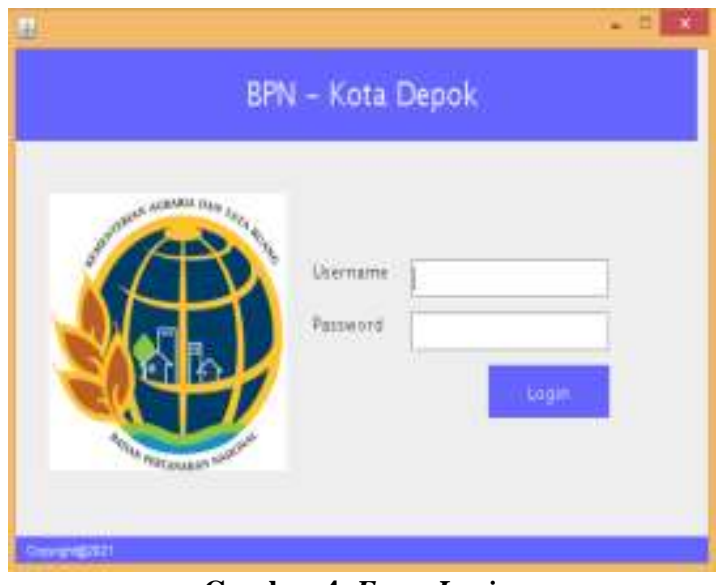

Gambar 4. Form Login

Tampilan ini terdapat pada awal program. Menu login digunakan sebagai kata kunci sebelum memasuki program utama. Agar tidak sembarang orang dapat mengakses program ini. Sehingga dalam Form menu kerahasiaannya tetap terjaga dengan baik. Apabila pengguna dapat memasukkan nama pengguna dan kata kunci dengan tepat, maka menu utama akan tampil dan program siap untuk dijalankan.

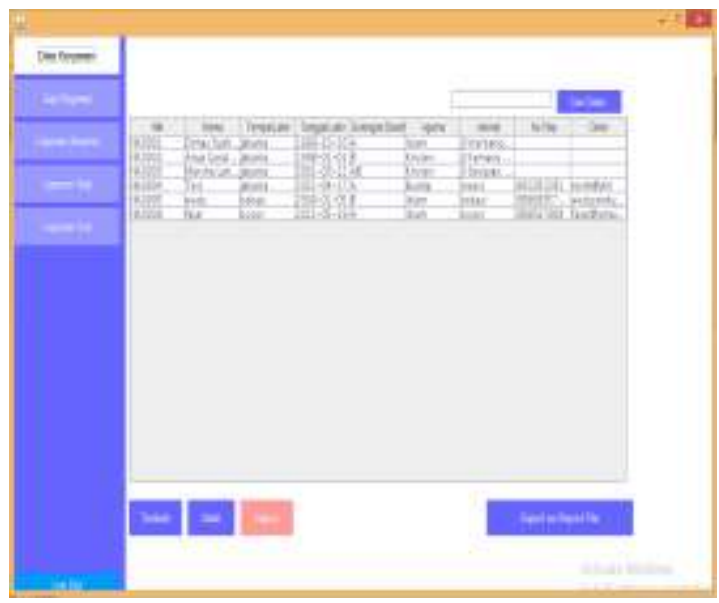

Gambar 5. Form Data Karyawan

Menu yang pertama adalah Data Karyawan yang berisikan tabel data seluruh karyawan. Pada bagian data karyawan ini digunakan untuk mengakses dengan mencari, menambah, mengubah, hapus dan cetak report data karyawan. User bisa mencari data karyawan yang diinginkan dengan memasukkan IdPegawai yang diingikan di cari data. 


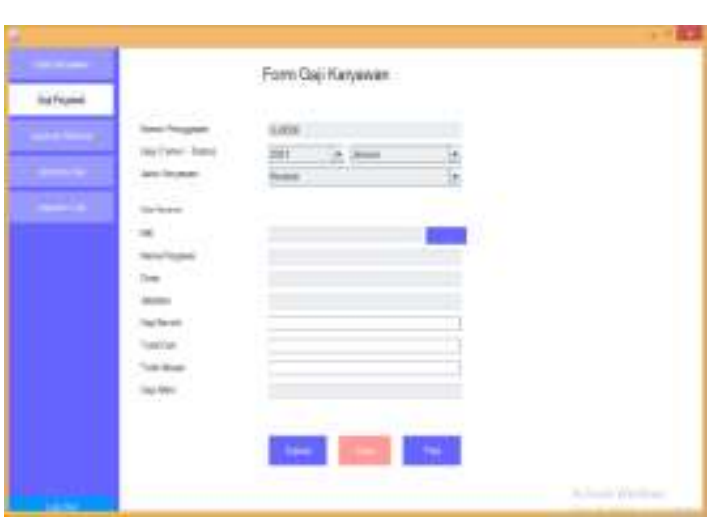

Gambar 6. Form Data Gaji Karyawan

Form di atas adalah form Gaji Pegawai pada bagian ini user dapat mengakses nomor penggajian, gaji, jenis karyawan, NIK, nama pegawai, divisi, jabatan, gaji bersih, total cuti, total absen, gaji akhir. Tentunya didalam menu ini terdapat icon submit, clear, dan print.

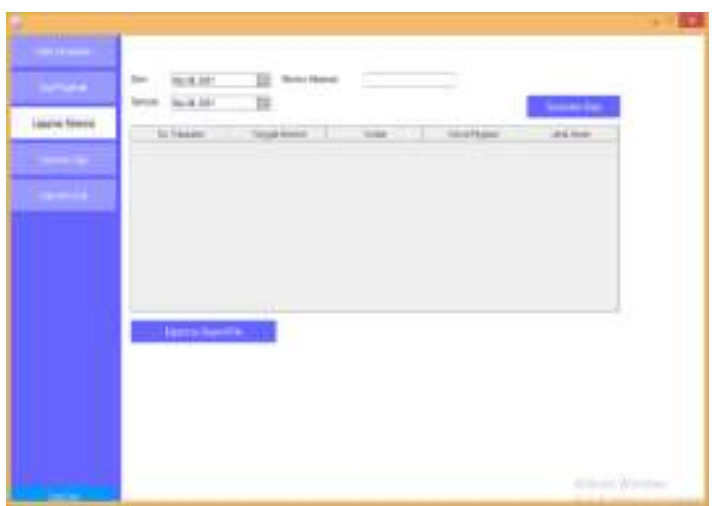

Gambar 7. Form Data Absensi

Layar tampilan diatas adalah menu Laporan Absensi yang digunakan untuk membuat laporan absen pegawai setiap bulannya. Menu ini mempunyai hak akses oleh bagian Kepegawaian, bagian Kepegawaian dapat memilih dan menampilkan periode laporan dengan nomer absensi pegawai secara Generate Data atau ditampilkan secara pertahun. Lalu bisa mencetaknya dengan mengklik icon "Export as Report file".

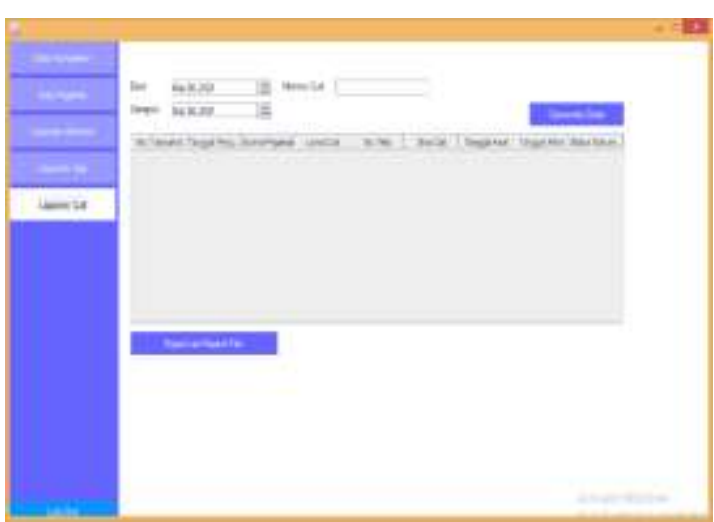

Gambar 8. Form Data Cuti

Layar tampilan diatas adalah menu laporan Cuti yang digunakan untuk menampilkan laporan Cuti setiap bulannya. Menu ini mempunyai hak akses oleh bagian Kepegawaian, bagian Kepegawaian dapat memilih dan menampilkan periode laporan dengan nomer penggajian pegawai secara Generate Data atau ditampilkan secara pertahun. Lalu bisa mencetaknya dengan mengklik icon "Export as Report file".

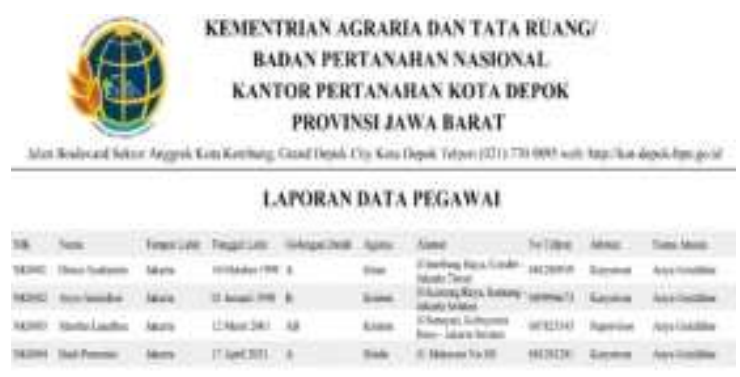

\section{Gambar 9. Laporan Data Pegawai}

Layar tampilan di atas adalah tampilan daftar data pegawai yang terdata pada sistem. Yang dapat diakses oleh bagian Kepegawaian. Data yang diinput dalam laporan tersebut berisikan data pegawai seperti NIK, Nama, Tempat lahir, Tanggal Lahir, Golongan Darah Agama, Alamat, No.Tlp, Jabatan, dan Nama Atasan. 


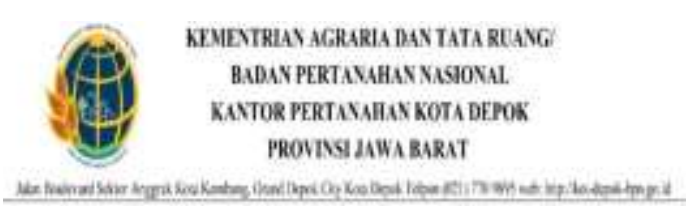

LAPORAN ABSEXSI PEGGWAI

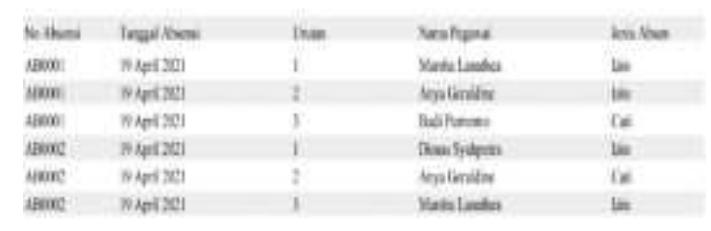

Gambar 10. Laporan Data Absensi

Layar Tampilan di atas menampilkan tampilan Form data Absensi pegawai. Bagian kepegawaian memiliki akses untuk membuat laporan ini dengan No.Absensi, Tanggal Absensi, Urutan, Nama Pegawai dan Jenis Absen.

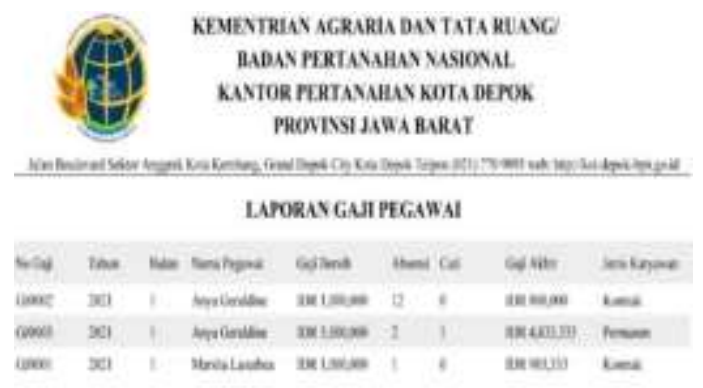

Gambar 11. Laporan Gaji Pegawai

Tampilan layar di atas menampilkan tampilan data setiap gaji pegawai. Untuk tampilan tersebut bagian Kepegawaian dapat mengakses No.Gaji, Tahun, Bulan Nama, Pegawai, Gaji, Bersih, Absensi, Cuti, Gaji akhir, dan Jenis Karyawan.

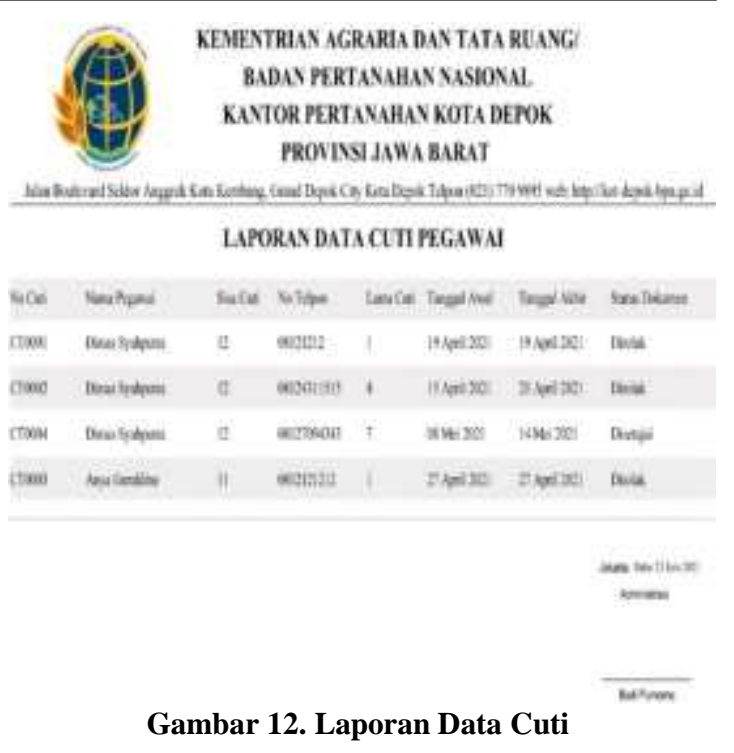

Tampilan layar di atas menampilkan tampilan data setiap laporan pegawai. Untuk tampilan tersebut bagian Kepegawaian dapat mengakses No.Cuti, Nama Pegawai,Sisa Cuti,No.tlp,Lama cuti, Tanggal Awal, Tanggal Akhir,Status Dokumen.

\section{SIMPULAN DAN SARAN}

Sistem informasi kepegawaian berbasis desktop ini dapat digunakan dengan mudah, dan meringankan pekerjaan sub bagian kepegawaian dalam menginput dan mencari data - data pegawai, membuat pengolahan data menjadi lebih efektif dan efisien, data yang disimpan di database lebih memudahkan dalam proses penyimpanan, sehingga mencegah hilangnya data dan duplikasi data. Tujuan dari penelitian ini adalah untuk menganalisis dan desain sistem kepegawaian berbasis desktop pada Kantor Pertanahan BPN Kota Depok. Hal ini dibuat untuk memastikan kelengkapan dan kebenaran data kepegawaian dan memberikan kemudahan bagi pegawai dan perusahaan untuk dapat melihat data kepegawaiannya sendiri. Metode ini menggunakan pengumpulan data, analisis (dengan survei, wawancara dan studi pustaka) dan desain (bentuk masukan, proses, laporan, dan database). Hasil dari penelitian ini adalah sistem kepegawaian berbasis desktop yang dapat digunakan oleh seluruh pegawai aktif selama 24 jam sehingga memudahkan pegawai yang di tempatkan di mana pun dan kapan pun untuk melihat data kepegawaiannya. 
Sarannya adalah Kantor Pertanahan BPN Kota Depok disarankan untuk terus mengimplementasikan sistem ini guna mendukung proses pengembangannya. Serta demi menjaga keamanan data untuk jangka waktu panjang, sebaiknya dilakukan backup data agar data yang disimpan tidak hilang atau terkena virus.

\section{DAFTAR PUSTAKA}

Fachlevi, M. R., \& Syafariani, R. F. (2017). Perancangan Sistem Informasi Kepegawaian Berbasis Website Di Bagian Kepagawaian Sdn Binakarya I Kabupaten Garut. Simetris: Jurnal Teknik Mesin, Elektro Dan Ilmu Komputer, $\quad 8(2), \quad 553$. https://doi.org/10.24176/simet.v8i2.143 6

Kodarisman, R., \& Nugroho, E. (2013). Evaluasi Penerapan Sistem Informasi Manajemen Kepegawaian ( SIMPEG ) di Pemerintah Kota Bogor. JNTETI ISSN:2301-4156.

Prasojo, M. (2011). Pengantar Sistem Informasi Manajemen. bandung: $\mathrm{CV}$. Remadja Karya.

Priansa, D. J. (2017). Manajemen Kinerja
Kepegawaian dalam Pengelolaan SDM Perusahaan. In Cetakan ke-1.

Putra, N. (2011). Research and Development, Penelitian dan Pengembangan: Suatu Pengantar. Jakarta: PT Raja Grafindo Persada.

Satzinger, J. W., Jackson, R. B., Burd, S. D. (n.d.). System Analysis and Design in A Changing World. USA: Cengage Learning.

Sugiyono. (2016). Metode Penelitian Kuantitatif, Kualitatif dan $R \& D$. Bandung: PT Alfabet.

Sutabri, T. (2012). Analisis Sistem Informasi. Yogyakarta: Andi.

Syarif, M., Pratama, E. B., Bina, U., Informatika, S., \& Barat, K. (2021). Implementasi Waterfall Sebagai Metode. Jurnal Informatika Kaputama (JIK), 5(1), 174-184.

Tani, E., Bagre, B., \& Adam, S. (2018). Perancangan Sistem Informasi Kepegawaian PT Sederhana Karya Jaya Berbasis WEB. Seminar Nasional Sistem Informasi Dan Teknologi Informasi 2018 SENSITEK 2018.

Tyoso, J. S. P. (2016). Sistem Informasi Manajemen. Yogyakarta: DeePublish. 